\title{
The Effect of Honeybee Pollination on Productivity and Quality of Strawberry
}

\begin{tabular}{|c|c|}
\hline Research / Araştırma & Ayşen Melda ÇOLAK ${ }^{1^{*}}$, Nuray ŞAHINLER ${ }^{2}$ \\
\hline $\begin{array}{l}\text { Received / Gelis Tarihi } \\
23.08 .2017\end{array}$ & $\begin{array}{c}\text { Mahmut ISLAMOĞL } \boldsymbol{U}^{3} \\
{ }^{1} \text { Usak University, Faculty of Agriculture and Natural Science, }\end{array}$ \\
\hline $\begin{array}{l}\text { Accepted / Kabul Tarih } \\
\text { 27.11.2017 }\end{array}$ & $\begin{array}{c}\text { Department of Horticulture, Uşak- Turkey } \\
{ }^{2} \text { Usak University, Faculty of Agriculture and Natural Science, }\end{array}$ \\
\hline $\begin{array}{l}\text { DOI } \\
\text { 10.28955/alinterizbd.335835 }\end{array}$ & $\begin{array}{c}\text { Department of Animal Science, Uşak-Turkey } \\
{ }^{3} \text { Usak University, Faculty of Agriculture and Natural Science, } \\
\text { Department of Plant Protection, Uşak-Turkey }\end{array}$ \\
\hline $\begin{array}{l}\text { ISSN 2564-7814 } \\
\text { e-ISSN 2587-2249 }\end{array}$ & *e-mail: aysenmelda.colak@usak.edu.tr \\
\hline
\end{tabular}

\begin{abstract}
: $90 \%$ of the food stuff all around the world is obtained from plants. $77 \%$ of these plant needs pollination by bees. Therefore, in order to achieve sufficient pollination, bee colonies are needed in florescence period. When pollination and fertilization do not occur in many species of horticultural crops, abscission takes place without the fruit's being able to complete its devolopment. In conditions where fecundation is insufficent, the shape of the fruits is deformed and product quality is low even if the fruits remain on the plant as a result of the formation of a few ovules. The quality and quantity of the productare directly affected by the formation, development, pollination and fertilization of flowers in horticutural crops such as apple, pear, strawberry, fig, kiwi, tomato, egg plant and pepper.When enough attention is paid to pollination, production growth in angio spermae is observed. In this study, according to the data obtained from a study conducted in order to determine the effect of honeybees on pollination and fecundation of strawberry in Usak province between 2014 and 2016, a considerable increase in quality and a homogeneity in strawberry fruit were observed and $1248.6 \mathrm{~g}$ of productivity was obtained in strawberries with bee pollination, while $970.33 \mathrm{~g}$ of productivity was obtained in strawberries without bee pollination.
\end{abstract}

Keywords: Strawberry, bees, yield, quality

\section{Çilekte Balarısının Verim ve Kaliteye Etkisi}

Öz: Dünya gıda maddelerinin \% 90'1 bitki türünden elde edilir. Bu bitki türlerinden \%77'si arı tarafından tozlaşmaya gereksinim duymaktadır. Bu nedenle yeterli tozlaşmayı sağlamak için çiçeklenme dönemlerinde arı kolonilerine ihtiyaç duyulmaktadır. Pek çok bahçe bitkileri türünde tozlanma ve döllenme olmadığı zaman meyveler gelişmelerini tamamlayamadan dökülürler. Döllenmenin yetersiz olduğu durumlarda, birkaç tohum taslağının oluşumu sonucu meyveler bitki üzerinde kalsa bile meyve șekli bozuk ve ürün kalitesi düşük olur. Elma, armut, çilek, incir, kivi, domates, patlıcan ve biber gibi bahçe bitkilerinde çiçeklerin oluşumu, gelişimi, tozlanma ve döllenme ile ürünün nitelik ve niceliği doğrudan etkilenmektedir. Tozlanmaya önem verildiğinde çiçekli bitkilerde ürün artışı olduğu gözlenmektedir. Bu çalışmamızda Uşak ilinde çilekte balarılarının tozlanma ve döllenmeye etkilerini belirlemek için 2014-2016 yılları arasında yürütülen çalışmada elde edilen verilere göre kalitenin önemli ölçüde arttı̆̆ 1 , çilek meyvelerinde homojenlik olduğu ve Ar1 polinasyonu olmayan çilekte verim 970,33 g iken Arılı polinasyondaki çilekte 1248,6 g verim elde edilmiştir.

Anahtar Kelimeler: Çilek, balarısı, verim, kalite

\section{INTRODUCTION}

Strawberry is one of the fruit species cultivated in many different ecologies.Strawberry, which is highly beneficial for human health and nutrition includes $\mathrm{B}$ and $\mathrm{C}$ vitamins, minerals such as calcium, iron, phosphorus and very little bromine, silicium, iodine and sulphur and facilitates the digestion because of the cellulose content and it is also known to have anti-cancer properties because it contains ellagicacid (Aybak, 2000). Strawberry is in berry fruits group pomologically and it is one of the plants that pollination difference is mostly observed. Pollination is necessary in strawberries for good fruit set. Honeybee activity is important for pollination and fecundation in strawberries.For that reason, 
bumblebees are used in greenhouse production, however; honeybees are used in outdoor production (Ağaoğlu and Gerçekçioğlu, 2013).

Use of insects in pollination creates the ecological balance by increasing amount and quality of products in agricultural production and ensuring the continuity of plants. However, in the fields where ecological balance cannot be created soil fertility is lost in time due to the erosion effect and plant populations cannot sustain their generations. The abundance of pollinators is effective even in the shortening of the florescence period in some plants. This provides to yield earlier and uniform products. However, when the pollination is not enough, small and malformed fruits are cultivated (Yavuksuz, 2006). Moreover, in recent years, the effective use of honeybees in pollination has gained importance in order to obtain more fertility from the unit area. For that reason, use of honeybees for an effective pollination in increasing the productivity of herbal products will contribute to the agriculture of our country. Importance of honeybees as both polinators of many plants and instead of decreasing wild polinators has been increasing day by day. Beekeepers, who try to get $20 \mathrm{~kg}$ honey per colony, in fact function effectively without noticing in pollination activities which have more economic importance than honey. When honeybees collect pollen and nectar from flowers to obtain nutrients, they provide pollination of many plants, including plants that are economically important (Evert and Eichborn, 2015). When the values of these plants pollinated through bees are considered as fruits, vegetables and seeds, this value reaches 8 billion US Dollars in the United States. The dependence of these plants with economic significance to insect polination and the role of bees in this polination have been identified. According to these data, in strawberries dependence to insect pollination has been determined as $40 \%$ and the role of honeybees in this pollination has been determined as $80 \%$ (Korkmaz, 2013). In our study an increase in strawberry productivity and quality and a homogeneity in strawberry fruit also were obtained similar to the data in literature.

\section{MATERIAL AND METHOD}

This study was conducted in Uşak between 2014 and 2016. Albion strawberry plant were used as plant materials in the trial. Trial random blocks were set up as 3 replications according to the trial design and each replication had 50 plants. The plants were planted in the banks with $30 \mathrm{~cm}$ high and $100 \mathrm{~cm}$ wide as $30 \times 30 \mathrm{~cm}$ between the plants. Watering was supplied through drip irrigation method and black polyethylene was used as mulch material in the study. Cold-stored bare rooted Albion strawberry plants were planted in June, 2014. In 2015 and 2016, as a bee material, a total of 5 colonies of 7-8 framed Anatolian hybrid bee genotypes with one old queen were placed at florescenceperiod of strawberries. In the pollination without bees the pollination was prevented by covering the top of strawberry trial with a net whose hole diameters prevented the bee pollination. In the trial the average of two years was taken by observing total yield (g), total fruit amount, yield per plant (g), fruit width $(\mathrm{mm})$, fruit height $(\mathrm{mm})$ and fruit weight.

\section{RESULTS AND DISCUSSION}

Total Yield (g), Total Fruit Amount (in number) and Yield per plant (g) obtained in the studies conducted in 2015 and 2016 in order to identify the effect of honeybee pollination in productivity and quality of strawberry are presented in Table 1 .

Table 1. Effect of Bee Pollination on Total Yield (g), Total Fruit Amount (in number) and Yield per plant $(\mathrm{g})$

\begin{tabular}{llll}
\hline & Yield (g) & $\begin{array}{l}\text { Fruit Amount } \\
\text { (number) }\end{array}$ & $\begin{array}{l}\text { Yield Per } \\
\text { Plant (g) }\end{array}$ \\
\hline Without Bees & $970.33 \pm 28.6^{\mathbf{a}}$ & $30.00 \pm 2.0^{\mathbf{a}}$ & $326.00 \pm 31.4^{\mathbf{a}}$ \\
\hline With Bees & $1248.6 \pm 31.4^{\mathbf{b}}$ & $36.00 \pm 2.6^{\mathbf{b}}$ & $540.00 \pm 33.00^{\mathbf{b}}$ \\
\hline
\end{tabular}

Effect of pollination with and without bee in productivity and quality of strawberry on Yield (g), Total Fruit Amount (in number) and Yield per plant (g) is presented in Table 1. When Table 1 is analyzed, the average yield in pollination without bees has beendetermined as $970,33 \pm 28,6 \mathrm{~g}$ while the average yield in pollination with bees has been determined as $1248.6 \pm 31.4 \mathrm{~g}$ Significant difference was found between pollination by bees and without bee in terms of average yield at $\mathrm{P}=0.001$ level. Average number of fruit in strawberry production without bees is determined as $36.00 \pm 2.0$ while it has been determined as $36.00 \pm 2.6$ using bee pollinator in strawberry production. Significant difference was also found between average number of fruit strawberry production with and without bees at the probability 
$\mathrm{P}=0.003$ level. When the yield per plant in strawberry production with and without bees is analyzed, , average yield per plant in productivity of strawberry without bees is determined as $326.00 \pm 31,4 \mathrm{~g}$, however, average yield per plant in productivity of strawberry with bees has been determined as $540,00 \pm 33.00 \mathrm{~g}$ The difference between average yield per plant in productivity of strawberry with and without bees has been determined as statistically significant at $\mathrm{P}=0.001$ level.

Effect of pollination with and without bee in productivity and quality of strawberry on fruit width $(\mathrm{mm})$, fruit length $(\mathrm{mm})$ and fruit weight $(\mathrm{g})$ is presented in Table 2.

Table2. Effect of honeybee pollination on fruit width $(\mathrm{mm})$, fruit length $(\mathrm{mm})$ and fruit weight $(\mathrm{g})$

\begin{tabular}{llll}
\hline & $\begin{array}{l}\text { Fruit Width } \\
(\mathbf{m m})\end{array}$ & $\begin{array}{l}\text { Fruit Length } \\
(\mathbf{m m})\end{array}$ & $\begin{array}{l}\text { Fruit Weight } \\
(\mathbf{g})\end{array}$ \\
\hline Without Bees & $27.13 \pm 0.76^{\mathbf{a}}$ & $35.86 \pm 1.87^{\mathbf{a}}$ & $11.31 \pm 0.34^{\mathbf{a}}$ \\
\hline With Bees & $30.10 \pm 0.35^{\mathbf{b}}$ & $36.39 \pm 0.80^{\mathbf{b}}$ & $13.02 \pm 0.23^{\mathbf{b}}$ \\
\hline
\end{tabular}

When Table 2 is analyzed, average fruit width in fruit samples taken from the strawberries fertilized by honeybees or not has been determined as $30.10 \pm 0.35 \mathrm{~mm}$ in fruits with bees, however; it has been determined as $27.13 \pm 0.76 \mathrm{~mm}$ in fruits without bees. The difference between fruit width of the fruits with or without bees has been determined as statistically significant $\left(\mathrm{t}_{2,4}=3.607 ; \mathrm{P}=0.025\right)$ and it has also been identified that fruit width of the fruits without bees and fruit width of the fruits with bees are in different groups in conducted statistical classification. Similarly, it has been determined that fruit length is also different between the fruits with and without bees. While the average fruit length in fruits without bees has been determined as $35.86 \pm 1.87 \mathrm{~mm}$, the average fruit length in the fruits with bees has been determined as $36.39 \pm 0.80 \mathrm{~mm}$. In conducted statistical evaluation, the difference between fruit lengths of fruit samples without bees and fruit lengths of fruit samples with bees has been determined as statistically significant $\left(\mathrm{t}_{2,4}=3.607 ; \mathrm{P}=0.025\right)$. The average fruit weights with and without bees has been determined as $11.31 \pm 0.34$ and $13.02 \pm 0.23$ respectively. In the statistical analysis applied on average fruit weights it has been determined that the difference between the averages is significant $\left(\mathrm{t}_{2,4}=12.59 ; \mathrm{P}=0.008\right)$ and both averages are in different groups.

It has been identified that pollination should be realized by honeybees in $90 \%$ in order to harvest more and higher quality fruits in strawberries (Özbek, 2008). Velthuis et al. in their studies in 2002 stated that honeybees are used as pollinators in more than 30 countries in the world and in 25 different cultivated plants and there are also strawberries among these plants (Velthuis et al., 2002) Similarly, various times of honeybee visits to many berry fruits especially strawberries and fruit species with lots of seeds such as kiwis provide a remarkable increase in seed numbers and this enables the fruits to have smooth shapes and high taste and flavour (Blanket et al., 1991; Goodwin et al., 1991; Svenson, 1991). In an another conducted study it has been found that the honeybees provide a significant increase in strawberry pollination compared to wind and small insects pollination and the highest yield has been obtained from the field allowed free for honeybee entrance with $2320,8 \mathrm{~g} / \mathrm{m}^{2}$ and the field where insects smaller than honeybees morphologically with $1387,8 \mathrm{~g} / \mathrm{m}^{2}$ and the wind are effective with 733,1 g/m² (Kuvanc1 et al., 2010). Vithanage in 1990 harvested 227 fruits in avocados without bees although there are 788 fruits per tree when honeybee pollination is utilized (Vithanage, 1990). Our study is supported by the given resources.

\section{CONCLUSION}

To sum up, importance of honeybees as both polinators of many plants and instead of decreasing wild polinators has been increasing day by day. It has been observed with this study that the productivity and quality in strawberry have increased with the use of honeybees as pollinators. The use of honeybees for pollination in fruit cultivation will provide an increase in cultivating more and higher quality products in our country. When the role and importance of honeybees in pollination and its effective role in quality and quantity increase in the products are thoroughly understood, great developments will happen in agricultural structure. Moreover, the necessity to use bee colonies in fruit production areas, informing and encouraging producers in this issue will contribute to fruit cultivation and beekeeping in our country. 


\section{ACKNOWLEDGMENTS}

This study is summarized in The International Conference on Agriculture, Forest, Food Sciences and Technologies (ICAFOF)

\section{REFERENCES}

Aybak H.Ç. 2000. Strawberry Farming. Hasad Publishing, 118 s, İstanbul.

Ağaoğlu and Gerçekcioğlu, 2013. A book of berries

Blanket, Douault. P., Pouvreau. A., 1991. Kivi Fruit Pollinatio: Honeybee Behaviour and its İnfluence on the Fruit. The 6th International Symposium on pollination, Tilburg, The Netherlans, August 1990. Acta horticulturae 288:376-381.

Evert, R., Eichborn, S. E., 2015. Plant Growth and Reproduction (Part XI). Raven Biology of Plants (Loose

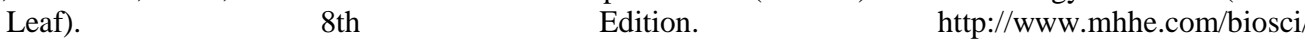
genbio/raven6b/graphics/raven06b/other/raven06_42.pdf.

Goodwin, R.M., Houten. A., Perry. J.H., 1991. Feeding Sugar Syrup to Honeybee Colonies to İmprove Kiwifruit Polen Collection. The 6th International Symposium on pollination, Tilburg, The Netherlans, August 1990. Acta horticulturae 288:265-269.

Korkmaz, A., 2013. Honey Bee Pollination. Samsun Provincial Directorate of Food, Agriculture and Animal Husbandry

Kuvanc1, A., Günbey, B., Konak, F., Karaoğlan, Y., 2010. The Effects of Honeybees and Other İnsects on the Pollination of the Strawberry Plant. Uludağ Bee MagazineFebruary2010: 1 (1): 28-34.

Svenson. B., 1991. The İmportance Of Honeybee Pollination For The Quality And Quantity Of Strawberries İn Central Sweden. The 6th International Symposium on pollination, Tilburg, The Netherlans, August 1990. Acta horticulturae 288:260-264.

Özbek, H., 2008.Insect Species Visiting Turkey's Temperate Climate Fruit Species Uludağ Bee Magazine, 8(3) 92-103.

Velthuis, H.H., Kevan, P., lmperatriz Fonseca, V., The historical background of the domestication of the bumblebee, bombus terrestris, and its introduction in agriculture, Pollinating Bees-The conservation link between agicutture and nature. Ministry of Environment, Sao Paulo, Brasil: p. 177-184,2002.

Vithanage, V., 1990. The rol of European Honeybee in Avocado Pollination. J. Hort. Sc1. 65, 81-86.

Yavuksuz, C., 2006.Effect of the Use of Honey Bee (Apis mellifera) and Bombus Bee (Bombus terrestris) as Pollens in the Production Areas of Sunflower (Helianthus annuus) Production and Yield. KSÜ, FBE, YL thesis. Kahramanmaraş. 